\title{
Feasibility study of fluorescent lamp waste recycling by thermal desorption
}

\author{
José María Esbrí ${ }^{1}\left[\right.$ - Sofía Rivera ${ }^{1} \cdot$ José Tejero $^{2} \cdot$ Pablo León Higueras ${ }^{1}$
}

Received: 16 June 2021 / Accepted: 24 September 2021 / Published online: 5 October 2021

(c) The Author(s) 2021

\begin{abstract}
The proposed Minamata Convention ban on the use of fluorescent lamps at the end of 2020, with a consequent reduction in mercury $(\mathrm{Hg})$ light products, is expected to produce large amounts of discarded fluorescent bulbs. In this context, the most effective recycling options are a thermal mercury recovery system and/or aqueous solution leaching (lixiviation) to recover rare earth elements (REEs). Due to the heterogeneous nature of these wastes, a complete characterization of $\mathrm{Hg}$ compounds in addition to a determination of their desorption temperatures is required for their recycling. The objective of this study is to assess the feasibility of a fast cost-effective thermal characterization to ameliorate recycling treatments. A pyrolysis heating system with a heat ramping capability combined with atomic absorption spectrometry makes it possible to obtain residue data with regard to the temperature ranges needed to achieve total $\mathrm{Hg}$ desorption. The major drawback of these heat treatments has been the amount of $\mathrm{Hg}$ absorbed from the residue by the glass matrices, ranging from 23.4 to $39.1 \%$ in the samples studied. Meanwhile, it has been estimated that $70 \%$ of $\mathrm{Hg}$ is recovered at a temperature of $437{ }^{\circ} \mathrm{C}$.
\end{abstract}

Keywords $\mathrm{Hg} \cdot$ Thermal desorption · Fluorescent lamp waste $\cdot$ The Minamata Convention $\cdot$ Recycling $\cdot$ Rare earth elements

Responsible Editor: Santiago V. Luis

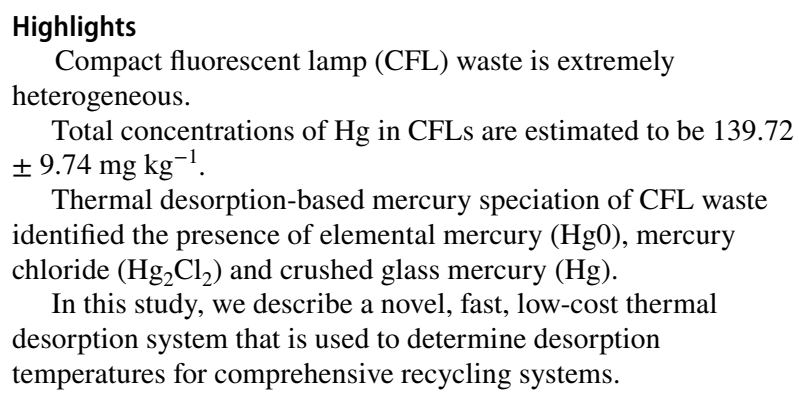

Thermal desorption-based mercury speciation of CFL waste identified the presence of elemental mercury $(\mathrm{Hg} 0)$, mercury chloride $\left(\mathrm{Hg}_{2} \mathrm{Cl}_{2}\right)$ and crushed glass mercury $(\mathrm{Hg})$.

In this study, we describe a novel, fast, low-cost thermal desorption system that is used to determine desorption temperatures for comprehensive recycling systems.

José María Esbrí

josemaria.esbri@uclm.es

1 Instituto de Geología Aplicada, Escuela de Ingeniería Minera e Industrial de Almadén, Universidad de Castilla-La Mancha, Plaza M. Meca 1, 13400 Almadén, Ciudad Real, Spain

2 Departamento de Mecánica Aplicada e Ingeniería de Proyectos, Universidad de Castilla-La Mancha, E.I.M.I. Almadén, 13400 Almadén, Ciudad Real, Spain

\section{Introduction and background}

The development of fluorescent lamps began in 1901 when Peter Cooper Hewitt invented the first mercury vapour lamp which emitted blue-green light. Nevertheless, the higher energy efficiency of these lamps led to further advances, culminating in the development by Germer, Meyer and Spanner in 1926 of tubes coated internally with fluorescent powder, which emitted white light. In 1980, the exterior design was modified to produce compact fluorescent lamps (CFLs).

A CFL consists of a copper $(\mathrm{Cu})$ electrode, an aluminium (Al) cap, a tungsten (W) sub-electrode sealed in lead glass, a glass tube, fluorescent coating material, $\mathrm{Hg}$, small amounts of argon (Ar) or krypton ( $\mathrm{Kr})$ and conductive $\mathrm{Cu}$ material (Lee et al. 2015). The fluorescent powder is basically composed of phosphorous compounds, most commonly derived from the following phosphates: $\mathrm{Ca}_{5}\left(\mathrm{PO}_{4}\right)_{3}\left(\mathrm{~F}_{0.9} \mathrm{Cl}_{0.1}\right)$, $\mathrm{Sr}_{5}\left(\mathrm{PO}_{4}\right)_{3}\left(\mathrm{~F}_{0.9} \mathrm{Cl}_{0.1}\right), \mathrm{Ca}_{5}\left(\mathrm{PO}_{4}\right)_{3}(\mathrm{~F}, \mathrm{Cl}): \mathrm{Sb}^{3+}, \mathrm{Mn}^{2+}$ and $(\mathrm{Ca}$, $\mathrm{Sr})_{10}\left(\mathrm{PO}_{4}\right)_{6}(\mathrm{~F}, \mathrm{Cl})_{2}: \mathrm{Sb}^{3+}, \mathrm{Mn}^{2+}$ (Anand and Singh 2021). A wide variety of phosphorous compounds are used depending on the colour of light required. For example, the patented fluorescent lamp CN101307231A contains $\mathrm{BaSiO}_{5} \mathrm{~Pb}$ (10-15\%), $3 \mathrm{Ca}_{3}\left(\mathrm{PO}_{4}\right)_{2} \mathrm{Ca}(\mathrm{F} . \mathrm{Cl})_{2} \mathrm{Sb}$ (55-65\%), $\mathrm{MgO}$. 
$\mathrm{MgF}_{2} \mathrm{CeO}_{28} \mathrm{Mn}(5-10 \%)$ and $(\mathrm{Zn} . \mathrm{Sr})_{3}\left(\mathrm{PO}_{4}\right) 2 \mathrm{Sn}(20-25 \%)$ (Guosong 2008). In addition, rare earth elements (REEs), such as yttrium (Y), cerium (Ce), lanthanum (La), terbium $(\mathrm{Tb})$ and europium (Eu), are commonly used (Anand and Singh 2021). Therefore, the recycling of this complex fluorescent light waste, containing large amounts of potentially toxic elements (PTEs) and REEs, can be economically viable but difficult to carry out.

The anthropogenic use of $\mathrm{Hg}$ worldwide, especially in its organic form, is highly toxic. Mercury, which has the capacity to travel long distances, is a global concern. In this context, the Minamata Convention (UNEP 2019) is aimed at protecting both the environment and human health against the adverse effects of mercury. Thus, technologies, such as fluorescent vapour lighting which uses and releases large quantities of $\mathrm{Hg}$ into the environment, were set to be banned by the end of 2020. These products, whose manufacture, export and import are prohibited, mostly concern the following: (i) general purpose CFLs ( $\leq 30 \mathrm{~W}$ ) containing up to $5 \mathrm{mg} \mathrm{Hg}$ per lamp unit; (ii) linear fluorescent lamps (LFLs); (iii) high-pressure mercury vapour lamps (HPMVLs); and (iv) cold cathode fluorescent lamps (CCFLs) and external electrode fluorescent lamps (EEFLs).

The consequent reduction in the use of mercury in fluorescent lighting is expected to generate large amounts of discarded products. Most of this waste will be deposited in landfills, along with other household waste, with only a small proportion being recycled: around 4-7\% in Canada, 23\% in the USA, 6\% in Brazil, 80\% in Austria and 95\% in Switzerland (de Farias et al. 2020; Silveira and Chang 2011). In Europe, waste electrical and electronic equipment (WEEE) directive 202/96/CE recommends a minimum recovery rate of $70 \%$, as well as a reuse and recycling rate of over $50 \%$, which will be technologically challenging to achieve.

CFLs can be recycled through the use of either thermal or chemical processes involving aqueous lixiviation (Durao et al. 2008). Generally, thermal desorption systems expose waste to high temperatures up to boiling point to recover mercury which is then converted into condensed vapour. Some systems also include a purification stage involving distillation or nitric acid bubbling processes. Several thermal desorption methods have been developed: Sweden's mercury recovery technology (MRT) system; end-of-life fluorescent lamp recycling technology developed by Nomura Kohsan in Japan; and the AERC and SepaDyne mercury recycling facilities in the USA (Rodríguez et al. 2012; Lee et al. 2015; Morris et al. 2002; TRU and Mixed Waste Focus Area 2002; Weyand et al. 1995). The most common recycling method used in Spain is based on the Swedish MRT system (Chang et al. 2007). This method includes an initial metal cap separation process, followed by the collection of fluorescent powder from the tubes, a glass crushing stage and $\mathrm{Hg}$ recovery involving distillation at temperatures of over $375{ }^{\circ} \mathrm{C}$ (Lee et al. 2015). These operational temperatures could be underestimates, as this type of waste normally requires temperatures of between 600 and $800{ }^{\circ} \mathrm{C}$ to ensure complete $\mathrm{Hg}$ removal due to the presence of $\mathrm{Hg}$ oxides when desorption temperatures exceed $375^{\circ} \mathrm{C}$ (Raposo et al. 2003). The whole process is performed under negative pressure conditions to prevent the release of $\mathrm{Hg}$ emissions into the atmosphere.

As the principal drawback of thermal treatments has always been their high cost, an appropriate balance between efficiency, temperature and treatment period needs to be found in order to make the process more cost-effective. The determination of minimum desorption temperatures depends on the heterogeneous nature of CFL residues. This study aims to find a cost-effective method to evaluate the optimum minimum temperature range for each CFL waste product in order to reduce total mercury content to below the legal limits laid down by the European Union directives.

\section{Experimental section}

Sampling was carried out over 5 consecutive days in May 2017. Each composite sample, weighing a total of $3 \mathrm{~kg}$ and containing CFL residues, was crushed in the recycling facility and then homogenized and mixed, prior to the extraction of an aliquot of $100 \mathrm{~g}$, and finally ground in an agate mortar for $5 \mathrm{~min}$ to ensure appropriate grain size.

A multielemental characterization was carried out with the aid of an Epsilon1 energy-dispersive X-ray fluorescence analyzer and the PanAlytical software. This enabled us to carry out four consecutive energy determinations of groups of elements from sodium (Na) to americium (Am) with similar matrix effects. Major and trace elements were quantified after editing the fluorescence spectra which were then quantified using the appropriate method, with the number of fluorescence signals detected for each element being changed accordingly. Sample analysis was carried out in duplicate to ensure representative results.

Total $\mathrm{Hg}$ and $\mathrm{Hg}$ compounds in the CFL residues were analysed using the Zeeman atomic absorption spectrometer (ZAAS) Lumex RA-915 M attached to a PYRO-915 + atomizer (Sholupov et al. 2004). Total $\mathrm{Hg}$ data were obtained by pyrolyzing each sample at $800{ }^{\circ} \mathrm{C}$ in order to atomize the $\mathrm{Hg}$ compounds. With its low detection limit $\left(2 \mathrm{ng} \mathrm{g}^{-1}\right)$, a high quantitative determination capacity of up to $2 \%$ and, due to the Zeeman effect, the negligible effect of matrices on the final results, this is the most effective technique for analysing these types of samples. Quality control was carried out by analysing certified reference material (NIST 2710a), with recovery rates of $98.5-107.2 \%$ being achieved. 
Mercury speciation studies were carried out using a Lumex RA-915 M device coupled with a PYRO$915+$ pyrolysis device, and specific temperature ramp software (Rumayor et al. 2016). This equipment enables different voltages, electrical resistances and time periods to be selected.

\section{Results and discussion}

\section{Multielemental and Total $\mathrm{Hg}$ characterization}

Multielement concentrations showed a predominance of silicon dioxide $\left(\mathrm{SiO}_{2}\right)$ in CFL residues, accounting for an average of $32.77 \%$ of the total, while $\mathrm{CaO}$ accounted for $15.13 \%$ and $\mathrm{Al}_{2} \mathrm{O}_{3}$ and $\mathrm{P}_{2} \mathrm{O}_{5} 8.89 \%$ and $8.77 \%$, respectively (Table 1). In addition, REE concentrations reached significant levels, with yttrium (Y) accounting for $6.77 \%$, and cerium $(\mathrm{Ce})$, europium $(\mathrm{Eu})$, terbium $(\mathrm{Tb})$ and lanthanum (La) representing only $0.57 \%, 0.43 \%, 0.38 \%$ and $0.34 \%$, respectively, of the total. Trace elements included sulphur trioxide $\left(\mathrm{SO}_{3} ; 835 \mathrm{mg} \mathrm{kg}^{-1}\right)$, titanium (Ti; $\left.704 \mathrm{mg} \mathrm{kg}^{-1}\right)$, zinc ( $\mathrm{Zn} ; 580 \mathrm{mg} \mathrm{kg}^{-1}$ ) and tungsten (W; $541 \mathrm{mg} \mathrm{kg}^{-1}$ ), as well as small amounts of copper $(\mathrm{Cu})$, tin $(\mathrm{Sn})$ and zirconium (Zr). The fluorescent tube glass in these residues, which has not been separated from the phosphorous powder, is thus a raw sample of the crushed tube. $\mathrm{Cu}$ concentrations are sufficiently low to rule out the presence of electrical parts of the tube in the residues. While these results accord with

Table 1 Statistical summary of multielement concentrations of CFL waste samples, expressed as a \% in the left column and in $\mathrm{mg} \mathrm{kg}^{-1}$ in the right column. Hg concentrations were analysed using ZAAS

\begin{tabular}{|c|c|c|c|c|c|}
\hline Element & Mass (\%) & SD & Element & Mass $\left(\mathrm{mg} \mathrm{kg}^{-1}\right)$ & SD \\
\hline $\mathrm{Al}_{2} \mathrm{O}_{3}$ & 8.89 & 1.09 & $\mathrm{SO}_{3}$ & 835.58 & 109.99 \\
\hline $\mathrm{SiO}_{2}$ & 32.27 & 1.39 & $\mathrm{Ti}$ & 704.10 & 125.43 \\
\hline $\mathrm{P}_{2} \mathrm{O}_{5}$ & 8.77 & 0.41 & Co & 43.72 & 61.45 \\
\hline $\mathrm{Cl}$ & 0.36 & 0.01 & $\mathrm{Ni}$ & 59.90 & 47.32 \\
\hline $\mathrm{K}_{2} \mathrm{O}$ & 1.19 & 0.19 & $\mathrm{Cu}$ & 312.90 & 41.01 \\
\hline $\mathrm{CaO}$ & 15.13 & 0.97 & $\mathrm{Zn}$ & 580.00 & 87.83 \\
\hline Mn & 0.13 & 0.01 & $\mathrm{Ge}$ & 108.48 & 17.01 \\
\hline $\mathrm{Fe}_{2} \mathrm{O}_{3}$ & 1.25 & 0.06 & $\mathrm{Te}$ & 113.72 & 14.43 \\
\hline $\mathrm{Sb}$ & 0.14 & 0.01 & W & 541.06 & 90.85 \\
\hline $\mathrm{Ba}$ & 1.28 & 0.18 & $\mathrm{Hg}$ & 139.72 & 9.74 \\
\hline $\mathrm{La}$ & 0.34 & 0.02 & Th & 4.56 & 5.06 \\
\hline $\mathrm{Ce}$ & 0.57 & 0.14 & As & 126.10 & 60.88 \\
\hline $\mathrm{Pb}$ & 0.42 & 0.07 & $\mathrm{Br}$ & 174.24 & 61.97 \\
\hline $\mathrm{Eu}$ & 0.43 & 0.14 & $\mathrm{Rb}$ & 40.06 & 5.51 \\
\hline $\mathrm{Tb}$ & 0.38 & 0.10 & $\mathrm{Zr}$ & 243.24 & 21.14 \\
\hline $\mathrm{Sr}$ & 0.39 & 0.02 & Sn & 344.88 & 57.30 \\
\hline Y & 6.77 & 1.99 & & & \\
\hline
\end{tabular}

other CFL wastes (de Farias et al. 2020; Raposo et al. 2003), some residues contain phosphor powder while others contain glass bulbs. Some studies have identified the main elements, $\mathrm{Ca}, \mathrm{P}, \mathrm{Sr}, \mathrm{Na}, \mathrm{Ba}, \mathrm{Mg}, \mathrm{Sb}, \mathrm{K}, \mathrm{Mn}, \mathrm{Fe}$ and $\mathrm{Hg}$, in phosphor powder, with varying amounts of REEs such as $\mathrm{Y}, \mathrm{Eu}, \mathrm{Ce}$, Gd and La (Pavón et al. 2021); thus, tubes and other lamp parts contained the elements $\mathrm{Al}_{2} \mathrm{O}_{3}, \mathrm{SiO}_{2}$ and $\mathrm{Pb}$, as well as most trace elements. In addition, while REEs such as $\mathrm{Tb}$ were present in the waste studied, Gd was not found.

Total $\mathrm{Hg}(\mathrm{THg})$ in CFL samples ranged from 125.4 to $151.3 \mathrm{mg} \mathrm{kg}^{-1}$, with a very low variation coefficient of $6.9 \%$ observed over the 5 sampling days. These figures are much lower than those for spent CFL bulbs in other studies: $1430-13,300 \mathrm{mg} \mathrm{kg}^{-1}$ (Raposo et al. 2003) and $3418.34 \pm 269.26 \mathrm{mg} \mathrm{kg}^{-1}$ (Choi and Rhee 2017). Considerable $\mathrm{Hg}$ concentrations can be found in fluorescent glass bulbs, ranging greatly around the world from $8.27 \%$ (Jang et al. 2005), 13.66\% (Rey-Raap and Gallardo 2013) and $16.27 \%$ (dos Santos et al. 2010) to $21.6 \%$ (Taghipour et al. 2014) and 50\% (Hobohm et al. 2017). Thus, the CFL residue used in this study can be regarded as highly homogeneous, while the $\mathrm{Hg}$ content of different residues worldwide varies greatly, with, in addition, major differences in matrix/ fractionation effects. This heterogeneity on a global scale is an enormous obstacle to implementing generic recycling techniques for this type of waste. Thus, in order to adapt these techniques to the multielement contents of each CFL residue, it is essential to characterize various aspects of the waste, including total $\mathrm{Hg}$ and its matrix/fractionation effects. The use of thermal desorption is particularly recommended for rapid low-cost evaluation of these two factors. This study evaluates the feasibility of thermal speciation of mercury with the aid of a Lumex RA-915 M analyzer.

\section{Thermal speciation of $\mathrm{Hg}$}

The thermal desorption profiles of five samples in Fig. 1 show three clearly delimited $\mathrm{Hg}$ species: elemental $\mathrm{Hg}$ $\left(\mathrm{Hg}^{0}\right)$, released at $35-174{ }^{\circ} \mathrm{C} ; \mathrm{HgCl}_{2} / \mathrm{Hg}_{2} \mathrm{Cl}_{2}$, released at 174-367 ${ }^{\circ} \mathrm{C}$; and glass $\mathrm{Hg}$, released at $367-662{ }^{\circ} \mathrm{C}$. In fluorescent tubes, $\mathrm{Hg}$ is usually found in its elemental $\mathrm{Hg}^{0}$ form, which is ionized each time the light is switched on. The $\mathrm{Hg}$ compounds formed are therefore considered simple combinations of $\mathrm{Hg}^{0}, \mathrm{Hg}^{+1}$ and/or $\mathrm{Hg}^{+2}$, with the most accessible compounds, in this case mainly $\mathrm{Cl}$, having more affinity to $\mathrm{Hg}$. A similar analysis of phosphor powder from spent fluorescent tubes in Brazil has demonstrated the presence of four main species: $\mathrm{Hg}^{0}, \mathrm{HgCl}_{2}, \mathrm{Hg}_{2} \mathrm{Cl}_{2}$ and $\mathrm{HgO}$ (Raposo et al. 2003). However, this identification of $\mathrm{Hg}$ compounds cannot be regarded as fool proof. In some ways, the thermal desorption method for identifying $\mathrm{Hg}$ species is similar to the X-ray diffraction method for the identification of mineral phases, which also produces analytical results that need to 

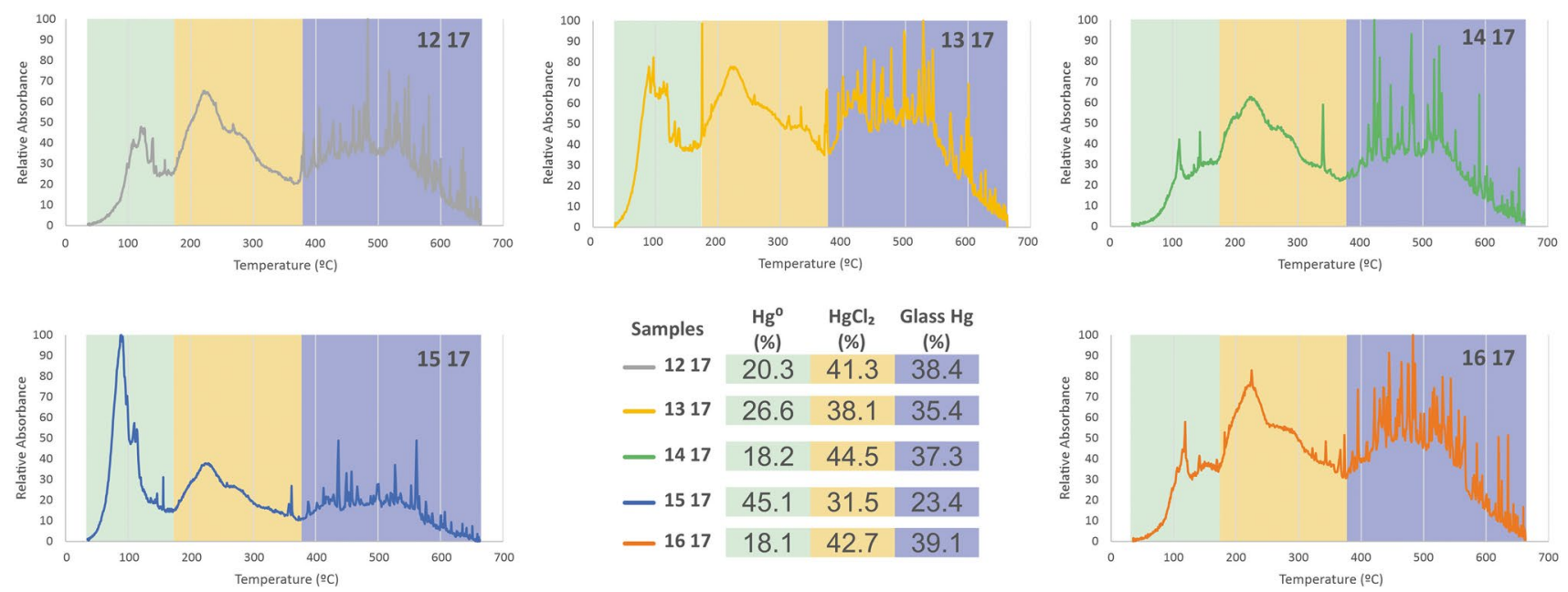

Fig. 1 Thermal speciation $\mathrm{Hg}$ profiles of CFL samples, showing desorption peaks of $\mathrm{Hg} 0$ (in green), $\mathrm{Hg}$ chlorides (in orange) and $\mathrm{Hg}$ adsorption by glass tubes (in blue). Relative proportions of these $\mathrm{Hg}$ compounds are shown in percentages

be interpreted by an experienced researcher who is familiar with the samples. Mercury compounds are desorbed at different temperatures, some of whose desorption ranges can overlap considerably. This is the case for many compounds, such as $\mathrm{HgBr}, \mathrm{HgI}, \mathrm{HgCl}_{2}$ and $\mathrm{Hg}_{2} \mathrm{Cl}_{2}$, as well as humic acid-bound and oxyhydroxide-bound $\mathrm{Hg}$ fractions, which desorb at around $200-225^{\circ} \mathrm{C}$. No humic acid-bound $\mathrm{Hg}$ has been found in discarded fluorescent bulbs despite the considerable information available on chemical elements (Table 1). For example, although there is sufficient $S$ for metacinnabar formation, X-ray fluorescence (XRF) analysis does not provide sufficiently clear data on fluorescent light elements capable of forming compounds with the $\mathrm{Hg}$ species $\mathrm{Hg}^{0}, \mathrm{Hg}^{+1}$ and $\mathrm{Hg}^{2+}$ present in discarded fluorescent tubes. Although the identification of the majority of species identified was based on data provided by the same technique (Raposo et al. 2003), our study sees the frequent peaks of the $\mathrm{Hg}$ species $\mathrm{Hg}^{2+}$ in desorption profiles as caused by the crushing of material containing $\mathrm{Hg}$, which is a typical cinnabar desorption profile from a geological sample. In addition, $\mathrm{HgO}$ is regarded as incapable of producing these successive peaks, suggesting a continuous crushing of structured material containing $\mathrm{Hg}$.

Nevertheless, the usefulness of these desorption graphs (Fig. 1) lies in the delimited temperature ranges, within which each compound is desorbed, especially those desorbed at above $375{ }^{\circ} \mathrm{C}$, at which all $\mathrm{Hg}$ is extracted from the sample using a traditional recycling system for this type of waste material. Also, species fractionation showed that the samples studies are highly homogeneous except for the sample 15 17, which with its higher $\mathrm{Hg}^{0}$ content does not maintain the proportion of species. It is important to note that $35-40 \%$ of total $\mathrm{Hg}$ in discarded fluorescent tubes is adsorbed to glass. When the desorption temperature for this
$\mathrm{Hg}$ compound was $367^{\circ} \mathrm{C}$ at the beginning of the process, the residues still contained $60 \mathrm{mg} \mathrm{kg}^{-1}$, or about $38 \%$ of THg at the initial stage of pyrolysis (Fig. 2). Like soils contaminated by mining and metallurgical activities, other residues desorb most of their $\mathrm{Hg}$ at $375{ }^{\circ} \mathrm{C}$ (Fig. 2). The samples come from contaminated mining soil in Almadenejos (Aj-200) and Almadén (N17 and N27) in Spain, the Czech Republic (JH1) and the USA (NIST 2710a); as well as metallurgical sites in Almadenejos (SCV samples). Speciation data for these samples show Hg compounds with desorption temperatures below the abovementioned limit of $375^{\circ} \mathrm{C}$, which are similar to those for metacinnabar $\left(280^{\circ} \mathrm{C}\right)$, methyl $\mathrm{Hg}\left(290^{\circ} \mathrm{C}\right)$, humic acid-bound $\mathrm{Hg}\left(220^{\circ} \mathrm{C}\right)$ and cinnabar $\left(305^{\circ} \mathrm{C}\right)$ (Campos et al. 2018).

CFL recycling regulations outlined in directive 202/96/ CE lay down a minimum recovery rate of $70 \%$, as well as a reuse and recycling rate of over $50 \%$ for CFL components, material and substances. This means that a $70 \%$ minimum recovery rate is mandatory for $\mathrm{Hg}$ in $\mathrm{CFL}$ residues, which requires a temperature of $437{ }^{\circ} \mathrm{C}$ to be reached in CFL samples (Fig. 2).

\section{Optimization of thermal desorption technique}

In order to determine the minimum working temperature in a recycling furnace to extract the highest possible amount of mercury from samples, an initial temperature ramp of $509{ }^{\circ} \mathrm{C}$ was selected. The efficiency of this heating ramp was verified using cinnabar, a naturally occurring mercuric sulphide $(\mathrm{HgS})$ from the Almadén mine in Spain, milled to a grain size of less than 70 microns and diluted in quartz powder. Maximum temperatures corresponded to the typical desorption temperature of $305{ }^{\circ} \mathrm{C}$ for cinnabar and $400{ }^{\circ} \mathrm{C}$ for $\mathrm{Hg}$ oxides in phosphorus powder (Rumayor et al. 2016). 

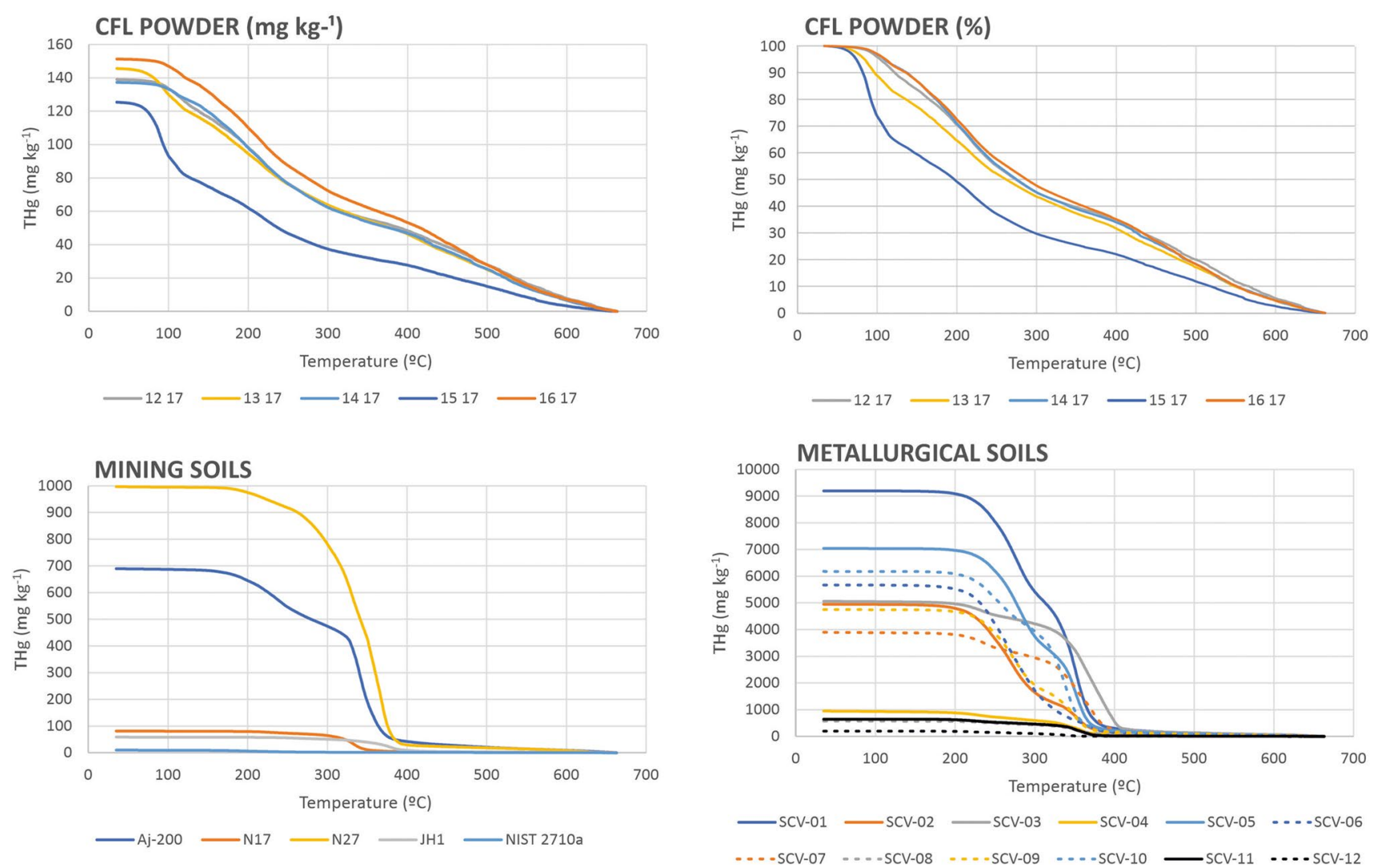

Fig. 2 Comparison of thermal desorption $\mathrm{Hg}$ profiles of some $\mathrm{Hg}$ waste products: CFL samples, as well as mining and metallurgical soils

During this process of optimization, several factors were found to affect the precise determination of mercury desorption temperatures: the grain size of the sample, which should not exceed 100 microns; electrical resistance/voltage changes, which should not lead to rapid heating of samples that would increase desorption; the position and quantity of the sample in the boat (sample holder), which should be systematically regulated; and air flow which was enhanced at higher rates $\left(3 \mathrm{~L} \mathrm{~min}^{-1}\right)$.

Most critical parameters were flow rate and homogenization of heat ramp. To optimize these parameters, some tests were carried out with different flow rates and different degrees of homogenization of the heating ramps.

In the equipment used in this work, the heating ramp is designed by assigning increasing voltages to the different units of the pyrolyzer. The first heating ramps smoothed out long desorption times and had too abrupt voltage jumps. This produced an increase in desorbed $\mathrm{Hg}$ coinciding with the voltage jumps of the heating ramp. This effect can be perfectly observed in Fig. 3a, in which the onset of several desorption peaks coincides with the rapid increase in temperature. To soften this effect and design a homogeneous heating ramp in terms of temperature, two parameters were modified, the magnitude of the voltage increase steps and the total time, reducing both until achieving a linear ramp with no effect on the desorption peaks (Fig. 3b).

Figure $3 \mathrm{c}$ shows how the flow rate affects the recorded desorption temperature. An evident delay is observed between the sample that has been desorbed at a lower flow rate $\left(1 \mathrm{~L} \mathrm{~min}^{-1}\right)$ and the one that desorbed at $3 \mathrm{~L} \mathrm{~min}^{-1}$. This is most probably due to the length of the mercury path between the second unit of the pyrolyzer and the analytical cell, which in the design of this experiment is located in the high concentration cell, located outside the pyrolyzer, at the backside of the Lumex RA-915 M mercury analyzer. No improvement in peak definition has been observed, although it is an expected effect of high flow rates.

Finally, the configuration was optimized under the following conditions:

- Heating rate: $0.74{ }^{\circ} \mathrm{C} \mathrm{s}^{-1}$

- Heating range: $35-660^{\circ} \mathrm{C}$

- Sample mass: $20 \mathrm{mg}$

- Pyrolyzer air flow: $3 \mathrm{~L} \mathrm{~min}^{-1}$

- Cooling time intervals between successive determinations: $40 \mathrm{~min}$.

Using this configuration, incomplete desorption profiles were obtained, with over $20 \%$ of $\mathrm{Hg}$ still not released. The 
Fig. 3 Desorption profiles of method optimization. $\mathbf{a}$ and $\mathbf{b}$ Optimization of heat ramp. c

Optimization of flow rate

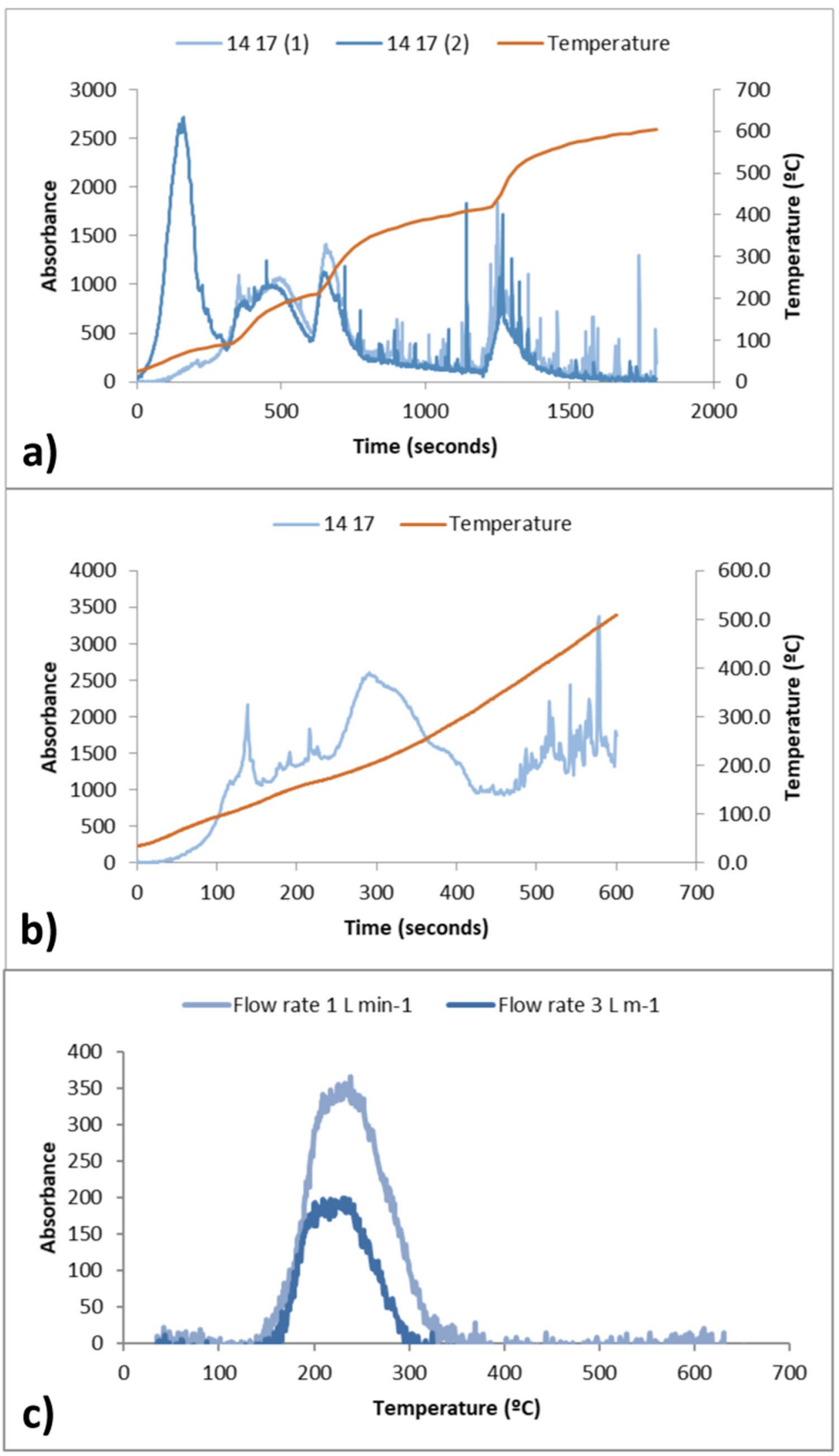


desorption profiles showed that the samples released mercury at the temperatures of $\mathrm{Hg}$ oxides, although another more refractory $\mathrm{Hg}$ compound remained unreleased. To resolve this problem, the temperature was ramped up to $660{ }^{\circ} \mathrm{C}$.

\section{Discussion}

Crushed fluorescent lamp waste, which is a mixture of phosphorous powder and crushed glass with very different levels of $\mathrm{Hg}$ content and other elements, including highly valuable REEs, can be considered a complex residue in terms of recycling capacity. The recycling strategy for these wastes currently combines a prior $\mathrm{Hg}$ thermal release stage and a subsequent leaching stage for usable elements, mainly REEs. This study, as well as others (Jang et al. 2005; Rey-Raap and Gallardo 2013; Taghipour et al. 2014; Hobohm et al. 2017), highlights the large amounts of $\mathrm{Hg}$ trapped in glass, which requires a high temperature of $437^{\circ} \mathrm{C}$ to achieve a recovery rate of at least $70 \%$. Some research describes the impact of thermal recovery treatment times on these waste products (Choi and Rhee 2017), with an optimal treatment time of $360 \mathrm{~min}$ at $400{ }^{\circ} \mathrm{C}$ for phosphorous powder using the reaction rate constant and activation energy. These promising results are dependent on the fractionation of $\mathrm{Hg}$ compounds in waste, especially those trapped in glass. It is important to note that CFL residues show large compositional differences between countries and between fluorescent lamp recycling companies (Binnemans et al. 2013), and that REEs are often recovered following the $\mathrm{Hg}$ recovery stage. Thus, a comprehensive and rapid characterization of mercury glass fractions is required in order to carry out thermal recovery treatments of such heterogeneous waste materials.

\section{Conclusions}

The restrictions proposed by the Minamata Convention (UNEP 2019) will lead to large quantities of waste containing $\mathrm{Hg}$ and REEs. The 2030 Agenda for Sustainable Development (United Nations 2015) calls on the world to "upgrade infrastructure and retrofit industries to make them sustainable, with increased resource-use efficiency and greater adoption of clean and environmentally technologies" by 2030 (Goal 9). This means that the problem of heterogeneous CFL waste could be resolved in a sustainable manner by combining two recycling methods in order to eliminate mercury and to recover REEs.

This study describes a fast, low-cost thermal mercury speciation system to accurately determine optimal desorption temperatures for CFL residues using atomic absorption spectrometry.
Although the study describes the combined use of a Lumex RA-915 device, a pyrolysis device and an atomic absorption spectrometer determine the desorption temperatures on an industrial scale.

We recommend the following conditions:

- Continuous heating from 35 to $660{ }^{\circ} \mathrm{C}$, while avoiding accelerations that could cause early $\mathrm{Hg}$ desorption.

- A high flow rate of $3 \mathrm{~L} \mathrm{~min}^{-1}$ to ensure more accurate determination of desorption temperatures.

- A heat rate of $0.74{ }^{\circ} \mathrm{C} \mathrm{s}^{-1}$.

- Cooling time of $40 \mathrm{~min}$ to ensure an appropriate starting temperature.

Acknowledgements We wish to thank Michael O'Shea for proofreading the manuscript.

Author contribution José María Esbrí, researcher, $\mathrm{PhD}$, as responsible of the manuscript entitled "Feasibility study of fluorescent lamp waste recycling by thermal desorption", authored by myself and Sofía Rivera-Jurado, MsC, José Tejero, PhD and Prof. Pablo Higueras, PhD. On behalf of the rest of the coauthors, with this document I warrantee and sign that the contributions done by the listed authors have been the following:

- Conceptualization: JME, PH, JT; formal analysis: JME, SRJ, PH; documentation and research: JME, SRJ, PH; methodology: JME, PH; resources/funding: JT, PH.

Funding Open Access funding provided thanks to the CRUE-CSIC agreement with Springer Nature. UCTR170068-Universidad de Castilla-La Mancha.

Availability of data and materials José María Esbrí, researcher, $\mathrm{PhD}$, as responsible of the manuscript entitled "Feasibility study of fluorescent lamp waste recycling by thermal desorption", authored by myself and Sofía Rivera-Jurado, MsC, José Tejero, PhD and Prof. Pablo Higueras, $\mathrm{PhD}$. On behalf of the rest of the coauthors, with this document I warrantee and sign that the datasets generated and used during the current study are available from the corresponding author on reasonable request.

\section{Declarations}

Ethical approval José María Esbrí, researcher, $\mathrm{PhD}$, as responsible of the manuscript entitled "Feasibility study of fluorescent lamp waste recycling by thermal desorption", authored by myself and Sofía RiveraJurado, MsC, José Tejero, PhD and Prof. Pablo Higueras, PhD. On behalf of the rest of coauthors, with this document I warrantee and sign that:

The manuscript has not been submitted to more than one journal for simultaneous consideration.

The submitted work is original and has not been published elsewhere in any form or language (partially or in full).

This is not a single study splitted up into several parts to increase the quantity of submissions and submitted to various journals or to one journal over time.

The results have been, to out intention, presented clearly, honestly and without fabrication, falsification or inappropriate data manipulation of any kind. 
No data, text or theories by others are presented as if they were ours. Proper acknowledgements to other works have been done: Summarized and/or paraphrased quotation marks (to indicate words taken from another source) are used for verbatim copying of material, and permissions secured for material that is copyrighted.

Consent to participate José María Esbrí, researcher, $\mathrm{PhD}$, as responsible of the manuscript entitled "Feasibility study of fluorescent lamp waste recycling by thermal desorption", authored by myself and Sofía Rivera-Jurado, MsC, José Tejero, $\mathrm{PhD}$ and Prof. Pablo Higueras, $\mathrm{PhD}$. On behalf of the rest of the coauthors, with this document I warrantee and sign that all authors whose names appear on the submission:

1) made substantial contributions to the conception or design of the work and/or the acquisition, analysis or interpretation of data.

2) drafted the work or revised it critically for important intellectual content;

3) approved the version to be published; and

4) agree to be accountable for all aspects of the work in ensuring that questions related to the accuracy or integrity of any part of the work are appropriately investigated and resolved.

Consent for publication José María Esbrí, researcher, $\mathrm{PhD}$, as responsible of the manuscript entitled "Feasibility study of fluorescent lamp waste recycling by thermal desorption", authored by myself and Sofía Rivera-Jurado, MsC, José Tejero, PhD and Prof. Pablo Higueras, PhD. On behalf of the rest of the coauthors, with this document I warrantee and sign that this manuscript does not contains any individual person's data in any form (including any individual details, images or videos).

Competing interests The authors declare no competing interests.

Open Access This article is licensed under a Creative Commons Attribution 4.0 International License, which permits use, sharing, adaptation, distribution and reproduction in any medium or format, as long as you give appropriate credit to the original author(s) and the source, provide a link to the Creative Commons licence, and indicate if changes were made. The images or other third party material in this article are included in the article's Creative Commons licence, unless indicated otherwise in a credit line to the material. If material is not included in the article's Creative Commons licence and your intended use is not permitted by statutory regulation or exceeds the permitted use, you will need to obtain permission directly from the copyright holder. To view a copy of this licence, visit http://creativecommons.org/licenses/by/4.0/.

\section{References}

Anand A, Singh R (2021) Synthesis of rare earth compounds from phosphor coating of spent fluorescent lamps. Sep Purif Rev 50(1):96112. https://doi.org/10.1080/15422119.2020.1754240

Binnemans K, Jones PT, Blanpain B, Van Gerven T, Yang Y, Walton A, Buchert M (2013) Recycling of rare earths: separation \& purification reviews 15 A Critical Review. J Clean Prod 51:1-22. https://doi.org/ 10.1016/j.jclepro.2012.12.037

Campos JA, Esbrí JM, Madrid MM, Naharro R, Peco J, García-Noguero EM, Amorós JA, Higueras P (2018) Does mercury presence in soils promote their microbial activity? The Almadenejos case (Almadén mercury mining district, Spain). Chemosphere 201:799-806. https:// doi.org/10.1016/j.chemosphere.2018.02.163

Chang TC, You SJ, Yu BS, Kong HW (2007) The fate and management of high mercury-containing lamps from high technology industry. J Hazard Mater 141:784-792

Choi Y, Rhee S (2017) Evaluation of energy consumption in the mercury treatment of phosphor powder from spent fluorescent lamps using a thermal process. Sustainability (Switzerland) 9(11):2013. https:// doi.org/10.3390/su9112013

de Farias CV, Paulino JF, Barcelos DA, Rodrigues APDC, Pontes FVM (2020) Is mercury in fluorescent lamps the only risk to human health? A study of environmental mobility of toxic metals and human health risk assessment. Chemosphere 261.https://doi.org/ 10.1016/j.chemosphere.2020.128107

dos Santos EJ, Herrmann AB, Vieira F, Sato CS, Correa QB, Maranhao TA, Tormen L, Curtius AJ (2010) Determination of $\mathrm{Hg}$ and $\mathrm{Pb}$ in compact fluorescent lamp by slurry sampling inductively coupled plasma optical emission spectrometry. Microchem J 96:27e31. https://doi.org/10.1016/j.microc.2010.01.012

Durao WA, de Castro CA, Windmoller CC (2008) Mercury reduction studies to facilitate the thermal decontamination of phosphor powder residues from spent fluorescent lamps. Waste Manag 28(11):2311-2319

Guosong Z Patent CN101307231A (2008) Fluorescent powder composition. Available online: https://patents.google.com/patent/CN101 307231A/en. Accessed on 26 Jan 2021

Hobohm J, Krüger O, Basu S, Kuchta K, van Wasen S, Adam C (2017) Recycling oriented comparison of mercury distribution in new and spent fluorescent lamps and their potential risk. Chemosphere 169:618-626. https://doi.org/10.1016/j.chemosphere.2016.11.104

Jang M, Hong SM, Park JK (2005) Characterization and recovery of mercury from spent fluorescent lamps. Waste Manag 25:5e14. https:// doi.org/10.1016/j.wasman.2004.09.008

Lee C, Popuri SR, Peng Y, Fang S, Lin K, Fan K, Chang T (2015) Overview on industrial recycling technologies and management strategies of end-of-life fluorescent lamps in Taiwan and other developed countries. J Mater Cycles Waste Manag 17(2):312-323. https://doi. org/10.1007/s10163-014-0253-y

Morris MI, Osborne-Lee IW, Hulet GA (2002) Demonstration of new technologies required for the treatment of mixed waste contaminated with $\geq 260$ ppm mercury, U.S. Department of Energy Office of Science and Technology, 2002

Pavón S, Lorenz T, Fortuny A, Sastre AM, Bertau M (2021) Rare earth elements recovery from secondary wastes by solid-state chlorination and selective organic leaching. Waste Manag 122:55-63. https://doi. org/10.1016/j.wasman.2020.12.039

Raposo C, CarvalhinhoWindmöller C, DurãoJúnior WA (2003) Mercury speciation in fluorescent lamps by thermal release analysis. Waste Manag 23:879-886. https://doi.org/10.1016/S0956-053X(03) 00089-8

Rey-Raap N, Gallardo A (2013) Removal of mercury bonded in residual glass from spent fluorescent lamps. J Environ Manag 115:175e178. https://doi.org/10.1016/j.jenvman.2012.11.012

Rodríguez O, Padilla I, Tayibi H, López-Delgado A (2012) Concerns on liquid mercury and mercury-containing wastes: a review of the treatment technologies for the safe storage. J Environ Manag 101:197205. https://doi.org/10.1016/j.jenvman.2012.02.013

Rumayor M, Lopez-Anton MA, Díaz-Somoano M, Maroto-Valer MM, Richard J, Biester H, Martínez-Tarazona MR (2016) A comparison of devices using thermal desorption for mercury speciation in solids. Talanta 150:272-277. https://doi.org/10.1016/j.talanta.2015.12.058

Sholupov S, Pogarev S, Ryzhov V, Mashyanov N, Stroganov A (2004) Zeeman atomic absorption spectrometer RA-915+ for direct determination of mercury in air and complex matrix samples. Fuel Process Technol 85(6-7):473-485. https://doi.org/10.1016/j.fuproc. 2003.11.003

Silveira GTR, Chang SY (2011) Fluorescent lamp recycling initiatives in the United States and a recycling proposal based on extended producer responsibility and product stewardship concepts. Waste Manag Res 29:656-668. https://doi.org/10.1177/0734242X10383744

Taghipour H, Amjad Z, Jafarabadi MA, Gholampour A, Nowrouz P (2014) Determining heavy metals in spent compact fluorescent lamps (CFLs) and their waste management challenges: 
some strategies for improving current conditions. Waste Manag. 34:1251e1256. https://doi.org/10.1016/j.wasman.2014.03.010

TRU and Mixed Waste Focus Area (2002) The SepraDyneTM-raduce system for recovery of mercury from mixed waste, New York: Innovative Technology Summary Report, September, 2002

United Nations (2015) Transforming our world: the 2030 Agenda for Sustainable Development. Main Committee (A/70/L.1). Available at https://www.un.org/ga/search/view_doc.asp?symbol=A/RES/70/ 1\&Lang=E. Accessed 14/05/2021

UNEP (2019) Minamata Convention on Mercury. Text and annexes. Available online: https://www.mercuryconvention.org/Portals/11/
documents/Booklets/COP3-version/Minamata-Convention-bookl et-Sep2019-EN.pdf. Accessed on 26 Jan 2021

Weyand TE, Zugates TP, Rose MV (1995) Performance of MRS's commercial medium-temperature mercury desorption process. In: International Incineration Conference, Bellevue, WA, U.S.A., May, 1995

Publisher's note Springer Nature remains neutral with regard to jurisdictional claims in published maps and institutional affiliations. 